ARTICLE

\title{
Therapeutic B-cell depletion reverses progression of Alzheimer's disease
}

Ki Kim (1) 1,10, Xin Wang 1,10, Emeline Ragonnaud ${ }^{1,10}$, Monica Bodogai ${ }^{1,10}$, Tomer Illouz (1) 2,3,4, Marisa DeLuca (D) 1 , Ross A. McDevitt ${ }^{5}$, Fedor Gusev ${ }^{6}$, Eitan Okun (1D) ${ }^{2,3,4}$, Evgeny Rogaev $6,7,8,9$ \& Arya Biragyn (iD) ${ }^{1 凶}$

The function of B cells in Alzheimer's disease (AD) is not fully understood. While immunoglobulins that target amyloid beta $(A \beta)$ may interfere with plaque formation and hence progression of the disease, $B$ cells may contribute beyond merely producing immunoglobulins. Here we show that $A D$ is associated with accumulation of activated $B$ cells in circulation, and with infiltration of $B$ cells into the brain parenchyma, resulting in immunoglobulin deposits around $A \beta$ plaques. Using three different murine transgenic models, we provide counterintuitive evidence that the $A D$ progression requires $B$ cells. Despite expression of the $A D$-fostering transgenes, the loss of $B$ cells alone is sufficient to reduce $A \beta$ plaque burden and disease-associated microglia. It reverses behavioral and memory deficits and restores TGF $\beta^{+}$microglia, respectively. Moreover, therapeutic depletion of B cells at the onset of the disease retards AD progression in mice, suggesting that targeting $B$ cells may also benefit $A D$ patients.

\footnotetext{
${ }^{1}$ Immunoregulation Section, Laboratory of Immunology and Molecular Biology, National Institute on Aging, Baltimore, MD, USA. ${ }^{2}$ The Mina and Everard Goodman faculty of Life Sciences, Ramat Gan, Israel. ${ }^{3}$ The Gonda Brain Research Center, Bar Ilan University, Ramat Gan, Israel. ${ }^{4}$ The Paul Feder Laboratory on Alzheimer's disease research, Bar Ilan University, Ramat Gan, Israel. ${ }^{5}$ Mouse Phenotyping Unit, Comparative Medicine Section, National Institute on Aging, Baltimore, MD, USA. ${ }^{6}$ Department of Genomics and Human Genetics, Institute of General Genetics, Russian Academy of Sciences, Moscow, Russia. ${ }^{7}$ Center for Genetics and Genetic Technologies, Faculty of Biology, Faculty of Bioengineering and Bioinformatics, Lomonosov Moscow State University, Moscow, Russia. ${ }^{8}$ Department of Psychiatry, University of Massachusetts Medical School, Worcester, MA, USA. ${ }^{9}$ Sirius University of Science and

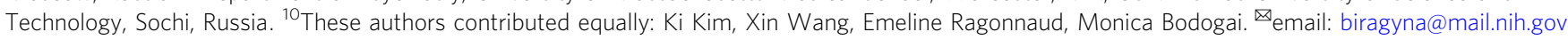


lzheimer's disease $(\mathrm{AD})$ is a progressive neurodegenerative disease that mostly affects elderly people. It is associated with impaired clearance of toxic protein aggregates from the brain parenchyma, such as amyloid- $\beta(A \beta)$ peptides of aberrantly cleaved amyloid precursor protein $(\mathrm{APP})^{1}$. Although resident microglial cells phagocytize extracellular $A \beta$ plaques with the help of astrocytes and TGF $\beta$ (refs. ${ }^{2,3}$ ), chronic inflammation, and $\mathrm{A} \beta$ production dysregulate this process, causing proliferation and subsequent replacement of homeostatic microglia with diseaseassociated microglia (DAM $)^{4}$. As in mice with genetic TGF $\beta$ deficiency, which suffer from microgliosis and neuronal death ${ }^{5}$, DAM further exacerbate neuroinflammation and neuronal degeneration in $\mathrm{AD}^{6,7}$, at least in part, through expression of proinflammatory cytokines and downregulation of phagocytosis of $\mathrm{A} \beta$ plaques $^{8-10}$. Consistent with a positive association between $\mathrm{AD}$ risk and old age ${ }^{11}$, when systemic inflammation is increased ${ }^{12}$, disease progression also depends on peripheral inflammation and activation of innate immune cells ${ }^{13}$. The role of the adaptive immunity in $\mathrm{AD}$ however remains poorly understood, and is mostly linked to $\mathrm{T}$ cells exerting both beneficial and harmful functions. For example, in APP/PS1 mice expressing the K670N and M671L Swedish mutations of human APP and L166P mutated presenilin 1 (PS1), the infiltration of Th1 CD4 ${ }^{+} \mathrm{T}$ cells in the brain either improves ${ }^{14}$ or exacerbates $\mathrm{AD}^{15}$. Moreover, the amelioration of $\mathrm{AD}$ in Rag2-deficient APP/PS1 mice is primarily linked to the loss of pathogenic T cells ${ }^{16}$. Although Rag deficiency also retards development of functional $\mathrm{B}$ cells (besides $\mathrm{T}$ cells), the role of $\mathrm{B}$ cells in $\mathrm{AD}$ is rarely explored and mostly considered to be beneficial. Their main product, nonspecific immunoglobulin and $\mathrm{A} \beta$-specific antibodies in peripheral blood $(\mathrm{PB})$ and cerebrospinal fluid (CSF) of people ${ }^{17,18}$ and mice ${ }^{19,20}$ with $\mathrm{AD}$, provides neuroprotective benefit. In $5 \times \mathrm{FAD}$ mice, which overexpress APP with the Swedish (K670N, M671L), Florida (I716V) and London (V717I) mutations, and PS1 with M146L and L286V mutations, Rag deficiency exacerbates AD due to loss of nonspecific immunoglobulin that activates microglial phagocytosis and consequent clearance of $\mathrm{A} \beta$ plaques $^{21}$. However, $\mathrm{B}$ cells are a heterogenous population of cells. Their function and subset accumulation are regulated by the inflammatory milieu. For example, we recently reported that inflammaging activates monocytes to convert innate $\mathrm{Bla}$ cells into pathogenic $4-1 \mathrm{BBL}^{+} \mathrm{TNFa}^{+} \mathrm{MHC}-\mathrm{I}^{\mathrm{High}} \mathrm{B}$ cells (termed 4BL cells), which then induce cytolytic CD8 ${ }^{+} \mathrm{T}$ cells and insulin resistance in elderly humans, macaques, and mice 22,23 . However, the role of these or other activated B cells in agingassociated diseases, such as $\mathrm{AD}$ remains unknown.

Here, using three, widely utilized transgenic AD mouse models with or without genetic B-cell deficiency, we provide evidence and mechanistic insight that the loss of mature B cells alone is sufficient to markedly retard the AD progression. Although $\mathrm{B}$ cells are thought not to infiltrate the $\mathrm{AD}$ brain, we link their presence in the brain parenchyma to the disease progression. Importantly, therapeutic depletion of circulating $B$ cells at the onset of the disease eliminates B cells, and their immunoglobulin deposits in the brain and blocks the $\mathrm{AD}$ manifestation. Our data not only warrants a new look to $\mathrm{B}$ cells as pathogenic, $\mathrm{AD}$-promoting cells in humans with $\mathrm{AD}$, but also suggests that their $\mathrm{B}$ cells should be targeted to control the disease progression.

\section{Results}

To assess the involvement of $\mathrm{B}$ cells in $\mathrm{AD}$, we first performed a flow cytometry evaluation of B cells in the circulation of congenic and sex- and age-matched C57BL/6 (WT) and $3 \times \mathrm{TgAD}$ mice, a model for early-onset AD (EOAD, harbors the Swedish APP mutation, the M146V mutation on PS1 and the P301L in MAPT) ${ }^{24,25}$. Note: from here on and unless specified, we used aged (60-70 weeks old) female $3 \times \mathrm{TgAD}$ mice due to their more pronounced $\mathrm{AD}$-like symptom manifestation ${ }^{25}$. Compared with control mice, $3 \times \mathrm{TgAD}$ mice significantly upregulated the frequency and numbers of B cells in the circulation and secondary lymphoid organs (Supplementary Fig. 1A and not depicted; gating strategy is in Supplementary Fig. 9A), with innate CD5 ${ }^{+}$B1a and $\mathrm{CD}^{-}{ }^{-} \mathrm{B} 1 \mathrm{~b}$ cells $\left(\mathrm{CD} 11 \mathrm{~b}^{+}\right.$or/and $\mathrm{CD}^{2} 3^{-} \mathrm{CD} 43^{+} \mathrm{CD} 19^{+}$cells, respectively) markedly increased, and conventional $\mathrm{B} 2$ cells decreased in the spleen and cervical lymph nodes (cLN; Fig. 1A-C and Supplementary Fig. $1 \mathrm{~B}-\mathrm{D}$ ). The $3 \times \mathrm{TgAD}$ mice also contained higher amounts of activated B cells expressing IFN $\gamma$, IL6, IL10, and TGF $\beta$ in circulation than control mice (Fig. 1D-G), mostly within Bla cells and, at lesser extent B1b and follicular B cells (Supplementary Fig. 1E-H). The AD mouse B cells, particularly B1a cells, markedly upregulated 4-1BBL (Supplementary Fig. 1I, J), resembling pathogenic $\mathrm{B} 1 \mathrm{a}$ cells of aged subjects ${ }^{22,23}$ and suggesting their potential involvement in $\mathrm{AD}$. To test this possibility, we have generated B-cell-deficient $3 \times \mathrm{TgAD}$ mice (termed $3 \times$ TgAD-BKO, Supplementary Fig. $2 \mathrm{~A}$ ) by crossing $3 \times \mathrm{TgAD}$ mice with $\mathrm{J}_{\mathrm{H}} \mathrm{T}$ mice, which lack functional $\mathrm{B}$ cells due to the immunoglobulin $\mathrm{J}_{\mathrm{H}}$ locus deletion that terminates B-cell development at the pro-B cell stage ${ }^{26}$. When mice reached 50-60 weeks of age, they were evaluated for hippocampusdependent cognitive behavior, using the Morris water maze (MWM) task. During the 5-day hidden platform training, both $3 \times \mathrm{TgAD}$ and $3 \times \mathrm{TgAD}-\mathrm{BKO}$ mice showed comparable performance (not depicted). However, $24 \mathrm{~h}$ after the last training session, a probe trial conducted in the absence of the hidden platform, revealed that $3 \times \mathrm{TgAD}-\mathrm{BKO}$ mice spent a significantly longer time in the target quadrant than their $3 \times \mathrm{TgAD}$ littermates $(p=0.017, n=13-15$, Fig. $2 \mathrm{~A})$, indicating a stronger spatial memory of the platform's location. We also tested exploratory behavior anomalies using the open field arena (OFA, a commonly used assay in $3 \times \mathrm{TgAD}$ mice ${ }^{27,28}$ ). While $3 \times \mathrm{TgAD}$ mice exhibited reduced activity as compared with WT mice in the OFA, the impairment was no longer detectable in age-matched $3 \times \mathrm{TgAD}$ BKO littermates (left panel, one-way ANOVA $F(2,29)=21.68$, $p<0.0001$; WT vs $3 \times \mathrm{TgAD} p<0.0001,3 \times \mathrm{TgAD}$ vs $3 \times \mathrm{TgAD}$ BKO $p<0.0001, n=10-11$, and Fig. $2 \mathrm{~B}$ ), implying that $3 \times \mathrm{TgAD}$ associated behavioral impairments required B cells.

To confirm this conclusion, we tested APP/PS1 mice, another model of EOAD, that exhibit earlier AD pathology compared with $3 \times \mathrm{TgAD}$ mice $^{29}$. Of note: subsequent experiments were therefore conducted in female and male, 20-35-week-old mice. Flow cytometry evaluation of circulating B cells revealed that APP/PS1 mice also markedly upregulated B cells expressing IL10 (Fig. 2C) as in $3 \times$ TgAD mice (Fig. 1F). However, APP/PS1 mice did not upregulate $4-1 \mathrm{BBL}^{+} \mathrm{B}$ cells (presumably due to their relatively young age $\mathrm{e}^{22,23}$ ) despite a significant increase of B1a cells in circulation and the cLN compared with control littermates (Supplementary Fig. 2B, C). We next generated B-cell-deficient APP/PS1-BKO mice by crossing APP/PS1 and $\mathrm{J}_{\mathrm{H}} \mathrm{T}$ mice. Analysis of spatial learning using the MWM revealed that compared with age- and sex-matched APP/PS1 or WT littermates, B-cell deficiency significantly improved learning deficiency in APP/PS1 mice as evident by latency to reach the escape platform $(F(2,33=8.288, p=0.0012$; WT vs APP/PS1 $p=$ $0.0006, \mathrm{APP} / \mathrm{PS} 1$ vs APP/PS1-BKO $p=0.003, n=12$, Fig. $2 \mathrm{D})$; and in the number of platform region crossings in a probe test conducted $24 \mathrm{~h}$ following learning (Kruscal-Wallis ANOVA $p=0.0004$; WT vs APP/PS1 $p=0.0002$; APP/PS1 vs APP/PS1-BKO $p=0.028$, Fig. 2E). Consistent with the lack of exploratory behavior impairment in APP/PS1 mice ${ }^{30}$, no difference in exploratory behavior of our mice in the OFA (not depicted). Thus, the spatial learning impairments exhibited by APP/PS1 are B-cell dependent.

Because the memory impairments in EOAD are caused by accumulation of $A \beta$ plaques and hippocampal microgliosis ${ }^{31}$, we 
A

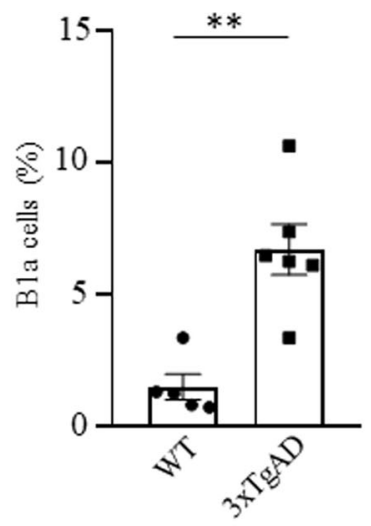

D

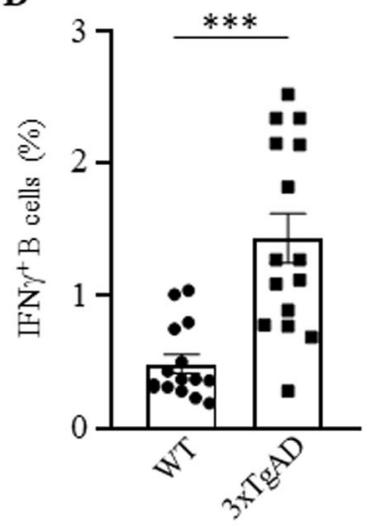

G

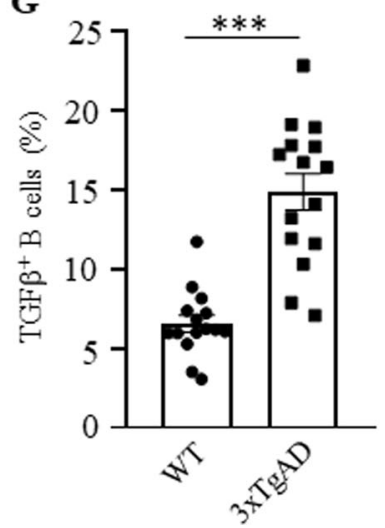

B

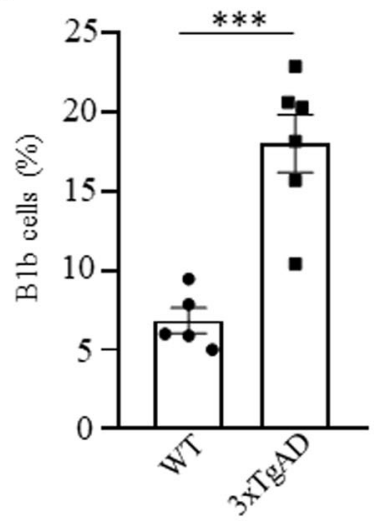

E



C



$\mathbf{F}$

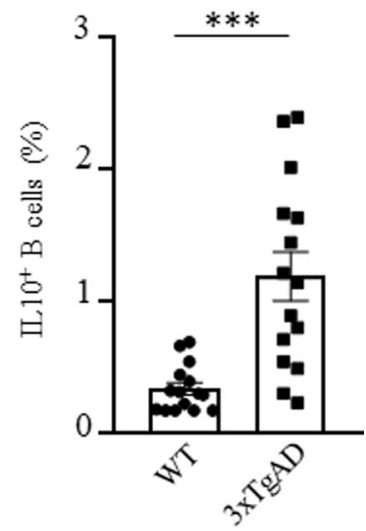

Fig. 1 Activated B cells were increased in $3 \times T$ TgAD mice. Compared with congenic, age- and sex-matched WT mice, $B 1 a\left(C D 5^{+} C D 11 b^{+} C D 19+, A\right)$ and $B 1 b$

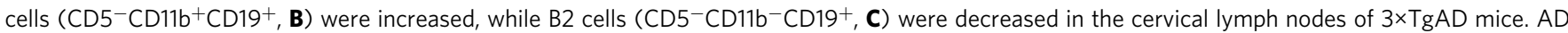
also activated B cells, as they upregulated IFN $\gamma(\mathbf{D})$, IL6 (E), IL10 (F), and TGF $\beta(\mathbf{G})$ in the peripheral blood of mice. Frequency (\%) mean \pm SEM is shown; each symbol is for a single mouse, $n=5-6$ in A-C, $n=15$ in D-G. Gating strategy is shown in Supplementary Fig. 9 A. ${ }^{\star \star} p<0.01 ;{ }^{\star \star \star} p<0.001$ in unpaired $t$ test.

conducted an immunofluorescent analysis for $\mathrm{A} \beta$ plaques (using the $6 \mathrm{E} 10 \mathrm{Ab}$ ) and ionized calcium binding adaptor 1 (Iba, a microglial cell marker) in cryopreserved brain sections of APP/ PS1-BKO (30 weeks old), 3×TgAD-BKO (60-70 weeks old) and age- and sex-matched control mice. Given that in this model the early intraneuronal $A \beta$ deposition in the subiculum is linked to cognitive impairments ${ }^{32}$, and that the subiculum and hippocampal CA1 atrophy is increased in $\mathrm{AD}$ patients ${ }^{33}$, from hereon we primarily analyzed the subiculum. It showed a marked upregulation of $\mathrm{A} \beta$ plaques in $\mathrm{APP} / \mathrm{PS} 1$ and $3 \times \mathrm{TgAD}$ mice (as compared with healthy control mice), which was reversed in $\mathrm{APP} / \mathrm{PS} 1-\mathrm{BKO}$ and $3 \times \mathrm{TgAD}-\mathrm{BKO}$ mice respectively $(n=4-7$, Fig. 3A-C and Supplementary Fig. 3A-D). Analysis of frontal cortex and hippocampus in $3 \times \mathrm{TgAD}-\mathrm{BKO}$ mice also revealed that the increase of soluble $A \beta_{42}$ and $A \beta_{40}$ was reversed $(n=2-6$, Fig. 3D and Supplementary Fig. 3E). Since both $3 \times \mathrm{TgAD}$ and $3 \times$ TgAD-BKO mice express high levels of the APP transgene in hippocampal neurons (Fig. 3E), we concluded that the benefit of the B-cell deficiency was probably in reduced formation and/or increased clearance of $A \beta$ peptides. Accordingly, large ameboid microglial cells $\left(>5 \mu \mathrm{m}^{2}\right)$, which indicate dysfunctional overactivation $^{34,35}$ and impaired clearance of $A \beta$ plaques $^{36}$, were significantly decreased in $3 \times \mathrm{TgAD}-\mathrm{BKO}$ mice to almost that of in WT mice $(p<0.05$, compared with $3 \times \mathrm{TgAD}, n=3-9$, Fig. $3 \mathrm{~F}$ and Supplementary Fig. 3F, G). In contrast, activated microglia (regardless of their size) remained increased in APP/PS1 and 
A



B

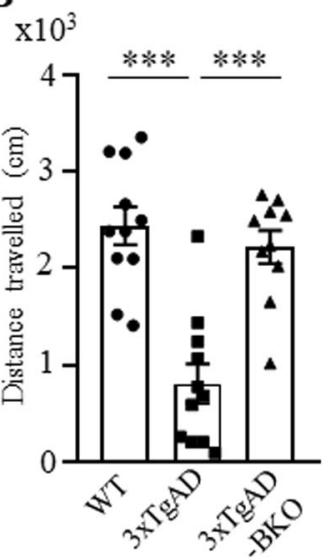

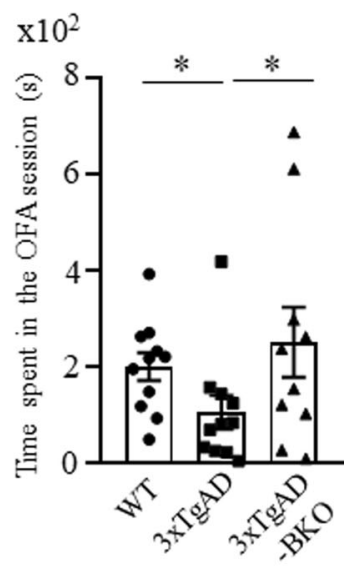

E

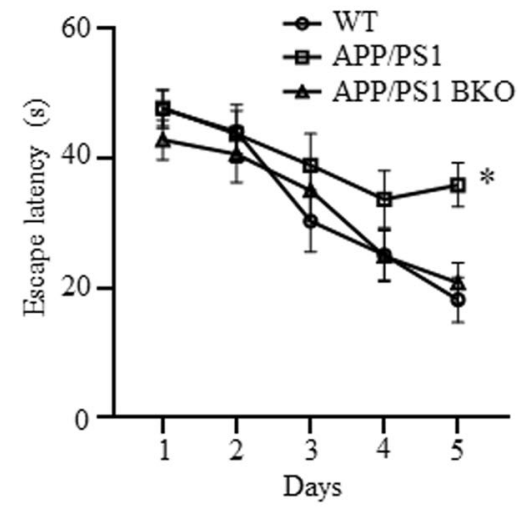

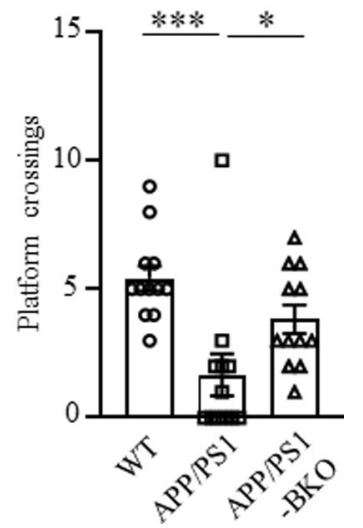

Fig. 2 Progression of AD required B cells. The impaired AD-associated cognitive ( $\mathbf{A}$, the MWM test) and noncognitive locomotion activity (B, total distance travelled, left panel, and time spent in center zone, right panel, in 30 min OFA test are shown) of $3 \times T g A D$ mice were improved in B-cell-deficient 3×TgAD-BKO mice ( $n=10-15$ female). Compared with WT littermate, APP/PS1 mice upregulated numbers of IL10+ B cells in the peripheral blood (C). The impaired cognitive ability of APP/PS1 mice (D, latency to reach the escape platform; $\mathbf{E}$, platform crossing times in a probe test in MWM test) was reversed in APP/PS1-BKO mice. Mean \pm SEM is shown; each symbol is for a single mouse. A, B and $\mathbf{D}$, E were independently reproduced three and two times, respectively. Gating strategy is shown in Supplementary Fig. 9A. ${ }^{\star} p<0.05 ;{ }^{\star \star \star} p<0.001$ in unpaired $t$ test (A), Mann-Whitney test (C), one-way ANOVA (B, left), Kruskal-Wallis test (B, right and $\mathbf{E}$ ) or two-way ANOVA (D).

APP/PS1-BKO mice (Fig. 3G and Supplementary Fig. 3H). To understand this discrepancy, we compared the function of microglia in these two models. Brain myeloid cells were isolated and stimulated with phorbol 12-myristate 13-acetate and ionomycin (PMAi, which induces microglial cytokine expression and proliferation ${ }^{37}$ ) for $4-6 \mathrm{~h}$ in the presence of monensin, and then surface markers and intracellular (IC) cytokines of microglia $\left(\mathrm{CD} 45^{\mathrm{Int}} \mathrm{CD} 11 \mathrm{~b}^{+}\right)$were analyzed using flow cytometry. The loss of B cells did not affect interleukin (IL) $1 \beta$ expression, which was markedly upregulated in both $3 \times \mathrm{TgAD}$ and APP/PS1 (Supplementary Fig. $4 \mathrm{~A}$ and Fig. $4 \mathrm{~A}$ and not depicted; gating strategy is in Supplementary Fig. 9B). In contrast, we noted a marked decrease in $\mathrm{TGF}^{+}$and IFN $\gamma^{+}$microglia (presumably quiescent and resting microglia ${ }^{38-40}$ ) in APP/PS1 and $3 \times \mathrm{TgAD}$ mice (Fig. 4B, C and Supplementary Fig. 4B-D). The TGF $\beta^{+}$(at lesser extent $\mathrm{IFN}^{+}$) microglial cells were normalized to the levels of WT control in APP/PS1-KO and $3 \times \mathrm{TgAD}-\mathrm{KO}$ mice (Fig. 4B, C and Supplementary Fig. 4B-D). Brain and hippocampal RNA microarray analyses indicated that B-cell deficiency prevented loss of TGF $\beta 1^{+}$microglia in the hippocampi and brains of $3 \times \mathrm{TgAD}$ mice, as its expression was upregulated (Fig. 4D) while DAM-related transcriptional signature genes, such as Itgax, Cst7, Clec7a, Mamdc2, and Saa3 (ref. ${ }^{4}$ ) were downregulated in $3 \times$ TgAD-BKO mice (Supplementary Fig. 4E, Supplementary
Data 1-3, and https://www.ncbi.nlm.nih.gov/geo/query/acc.cgi? $\mathrm{acc}=\mathrm{GSE} 165111)$. B-cell deficiency did not affect expression of $I L 1 \beta$ nor other DAM genes, such as TNF $\alpha$, Igfl, and Lilrb4 (Supplementary Fig. 4E and Supplementary Data 1-3). In sum, despite expression of AD-promoting transgenes, DAM accumulation, $A \beta$ plaque deposition, and thus the disease progression required $\mathrm{B}$ cells in both $3 \times \mathrm{TgAD}$ and APP/PS1 models of AD.

Next, we sought to test whether progression of EOAD can also be controlled by a therapeutic inactivation or depletion of $\mathrm{B}$ cells at the disease onset. To test this idea, $3 \times \mathrm{TgAD}$ mice $(60-70$ weeks old, female) were intraperitoneally injected with anti-CD20/B220 antibody (which depletes B cells in the circulation) for 2 months. Control mice were treated with isotype-matched IgG. The antiCD20/B220 Ab efficiently depleted B cells in the circulation (Supplementary Fig. 5A). Compared with control treated mice, the anti-CD20/B220 Ab-treated $3 \times \mathrm{TgAD}$ showed a trend toward increased activity in the OFA $(p=0.07,30 \mathrm{~min}, n=5$, Supplementary Fig. 5B). The treatment however significantly reduced the number of $\mathrm{A} \beta$ plaques in the subiculum of $\mathrm{AD}$ mice $(p<0.05$, Fig. 4E, F), but did not affect the number of large $\left(>50 \mu \mathrm{m}^{2}\right) \mathrm{Iba}^{+}$ microglial cells in the hippocampus (Supplementary Fig. 5C). To understand this discrepancy, we repeated anti-CD20/B220 Ab treatment in a different cohort of female $60-70$-week-old $3 \times \mathrm{TgAD}$ mice for 2 months $(n=6-7)$ and then performed a flow cytometry 
A

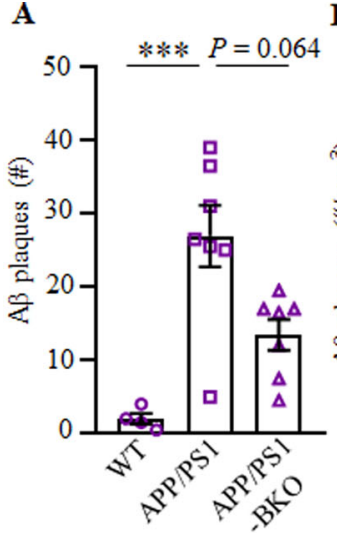

D

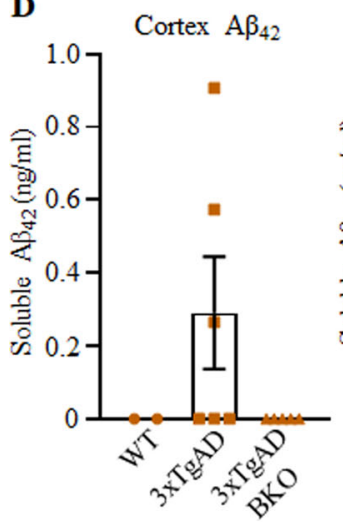

F

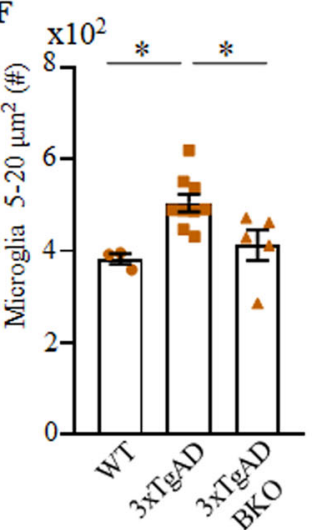

B

$\mathrm{x} 10^{3} * * *+*$
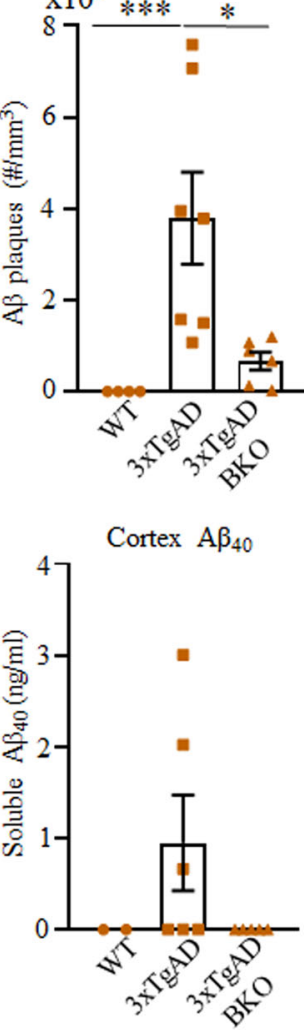

G

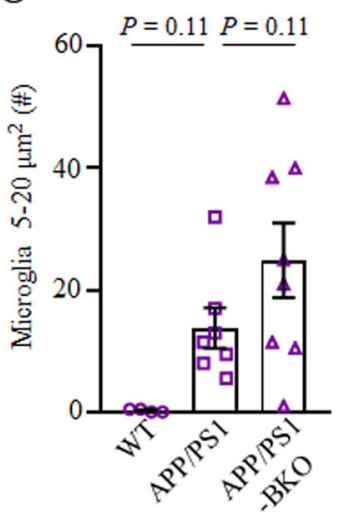

C

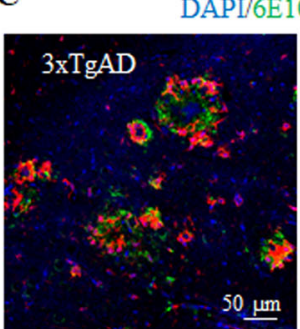

3xTgAD BKO

E $\times 10^{3}$



$50 \mu \mathrm{m}$

Fig. 3 B-cell deficiency reduced the $\mathbf{A} \boldsymbol{\beta}$ plaque burden and microglial activation in the hippocampus of $\mathbf{A D}$ mice. $\mathbf{A}-\mathbf{C}$ show the number of $A \beta$ plaques in APP/PS1 (A) and $3 \times \operatorname{TgAD}(\mathbf{B})$ mice $(n=4-7)$, and representative images of immune fluorescent staining of the subiculum of WT, $3 \times \operatorname{TgAD}$, and $3 \times \operatorname{TgAD}$ BKO mice (C, A $\beta$ plaque (green), Iba1+ microglia (red), and DAPI (blue); scale, $50 \mu \mathrm{m}$ ). D The increase of soluble $A \beta_{1-40}$ and $A \beta_{1-42}$ peptides in the brain of $3 \times T g A D$ mice was reversed in 3×TgAD-BKO mice. The results of ELISA in the cortex of indicated mice $(n=2-6)$ are shown. The B-cell deficiency did not affect expression of the transgene, as both $3 \times \operatorname{TgAD}$ and $3 \times \operatorname{TgAD}-\mathrm{BKO}$ highly expressed transgenic hAPP in hippocampal neurons (E, stained with 6 E10 as in B-C). The B-cell deficiency significantly decreased the number (\#) of large-sized microglia $\left(5-20 \mu \mathrm{m}^{2}\right)$ in $3 \times \operatorname{TgAD}(n=3-9$, F), but not in APP/PS1 mice $(n=4-8, \mathbf{G})$. Mean \pm SEM is shown; each symbol is for a single mouse. ${ }^{\star} p<0.05 ;{ }^{\star \star \star} p<0.001$; NS not significant in Kruskal-Wallis test $(\mathbf{A}, \mathbf{B}, \mathbf{G})$ or oneway $\operatorname{ANOVA}(\mathbf{E}, \mathbf{F})$.

evaluation of microglial cytokines in the perfused brains. As noted above, in $3 \times \mathrm{TgAD}-\mathrm{BKO}$ mice, B-cell depletion significantly reversed the decrease of $\mathrm{TGF}^{+}$and $\mathrm{IFN} \gamma^{+}$microglia in $3 \times \mathrm{TgAD}$ mice to almost the levels in WT mice (both in terms of frequency and numbers, $p<0.05$, Fig. $4 \mathrm{C}, \mathrm{G}$ and Supplementary Fig. 5D, E) while not affecting IL1 $\beta^{+}$microglia, which was comparably upregulated in aged $3 \times \mathrm{TgAD}$ and WT mice (Supplementary Fig. 5F).

To validate these results, we used a third mouse model of $\mathrm{EOAD}$, the $5 \times \mathrm{FAD}$ mice that develop a more aggressive $\mathrm{AD}$ pathology by 40 weeks of age because of a large burden of $A \beta$ plaques caused by additive effects of five familial $\mathrm{AD}$ mutations ${ }^{41}$. In this model, others have linked $\mathrm{AD}$ progression to a decrease in frequency of potentially beneficial $\mathrm{B} 1 \mathrm{a}$ cells $^{42}$. However, our cohorts of $5 \times \mathrm{FAD}$ mice did not exhibit a decrease in $\mathrm{B}$ cells, including B1a and B1b cells (both in terms of number and frequency), as compared with control age-matched littermates (Supplementary Fig. 6A, B). The B cells and B1 cells in $5 \times$ FAD mice instead appeared to be activated, as they significantly upregulated expression of 4-1BBL (Supplementary Fig. 6C, D). In concordance, IC cytokine staining of splenic cells revealed marked increase of IL10, TGF $\beta$, and IFN $\gamma$ in $B$ cells 
A

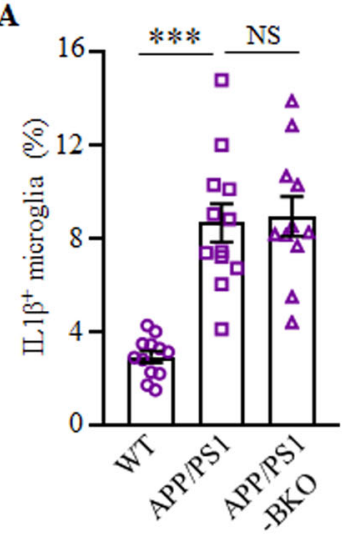

B



C



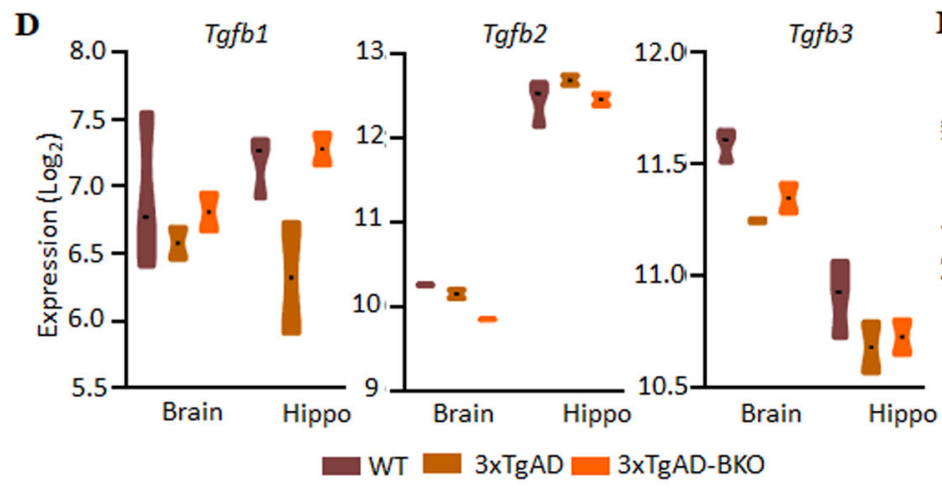

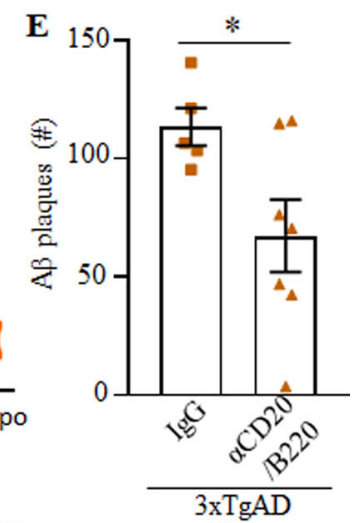

$\mathbf{F}$

G
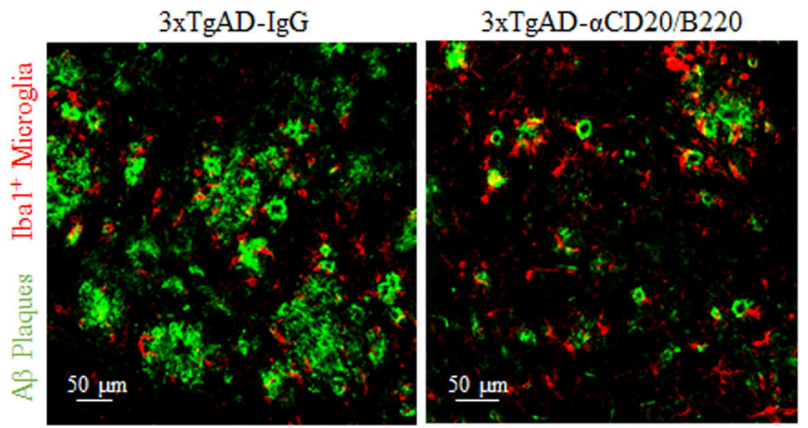

Fig. 4 B-cell deficiency at least in part reversed the DAM phenotype. The results of flow cytometric quantification of IL1 $\beta^{+}(\mathbf{A})$ and TGF $\beta^{+}(\mathbf{B}, \mathbf{C})$ microglia $\left(C D 11 b^{+} C D 45^{\text {int }}\right)$ in the brains of indicated mice $(n=11-12)$ are shown. Genetic B-cell deficiency in APP/PS1 mice (APP/PS1-BKO, B) or transient depletion of circulating $B$ cells $(a C D 20 / B 220, C)$ at the onset of $A D\left(70-79\right.$ weeks of age $3 \times T$ TgAD mice) reversed the AD-associated decrease of TGF $\beta^{+}$ microglia. mRNA microarray analyses of hippocampi and brains (without hippocampus) of $3 \times \operatorname{TgAD}$ mice revealed that the $B$-cell deficiency ( $3 \times \mathrm{TgAD}$ BKO) upregulates expression of TGF $\beta 1$, but not TGF $\beta 2$ and TGF $\beta 3$ ( $\mathbf{D}, n=3)$. Therapeutic depletion of $B$ cells (aCD20/B220) at the onset of AD ameliorated $A D(\mathbf{E}-\mathbf{G})$, as it markedly decreased $A \beta$ plaques in the subiculum (quantification and representative images are shown in $\mathbf{E}$ and $\mathbf{F}$, respectively; $\mathrm{A} \beta$ plaque (green) and $\mathrm{Iba} \mathrm{1}^{+}$microglia (red, $\left.\mathbf{F}\right), n=6-8$; independently reproduced twice). B-cell depletion reversed the reduction of IFN $\gamma^{+}$microglia in $3 \times \operatorname{TgAD}$ mice $(\mathbf{G}, n=5-7)$. Mean \pm SEM is shown; each symbol is for a single mouse. Gating strategy is shown in Supplementary Fig. $9 \mathrm{~B}$. ${ }^{\star} p<0.05$; ${ }^{* * *} p<0.001$ in one-way ANOVA $(\mathbf{A}-\mathbf{C}, \mathbf{G})$ or unpaired $t$ test $(\mathbf{F})$.

(Supplementary Fig. 6E). To test whether depletion of these activated $\mathrm{B}$ cells also ameliorates $\mathrm{AD}, 5 \times \mathrm{FAD}$ mice $(35-47$ weeks old, female) were i.p. injected with anti-CD20/B220 Ab or control $\operatorname{IgG}(n=7-12)$ for 2 months. Mice were then evaluated in the OFA for exploratory behavior and anxiety. While control IgGtreated $5 \times \mathrm{FAD}$ mice showed reduced exploratory behavior compared with WT littermates, this effect was reversed in B-celldepleted mice $(F(2,25)=5.25, p=0.013$; wt vs $5 \times \mathrm{FAD} p=0.03$, $5 \times \mathrm{FAD}+\operatorname{IgG}$ vs $5 \times \mathrm{FAD}+\alpha \mathrm{CD} 20 p=0.02$, Fig. $5 \mathrm{~A})$. To confirm this result, we quantified $\mathrm{A} \beta$ plaques and activated microglia in the hippocampus of these mice. Compared with IgG treatment, B-cell depletion in $5 \times F A D$ mice significantly reduced the number of $\mathrm{A} \beta$ plaques (Fig. $5 \mathrm{~B}, \mathrm{C}$ ) and the large-sized $\mathrm{Iba1}^{+}$microglia (Fig. 5D). We repeated the 2-month B-cell depletion experiment in a different cohort of age-matched, female $5 \times \mathrm{FAD}$ and WT mice $(n=5-12)$, and evaluated microglial cells using flow cytometry in perfused with saline brains. Similar to $3 \times \mathrm{TgAD}$ and APP/PS1 mice, $\mathrm{TGF}^{+}$and $\mathrm{IL} 10^{+}$microglia were significantly 



E $\quad * * \quad P=0.07$
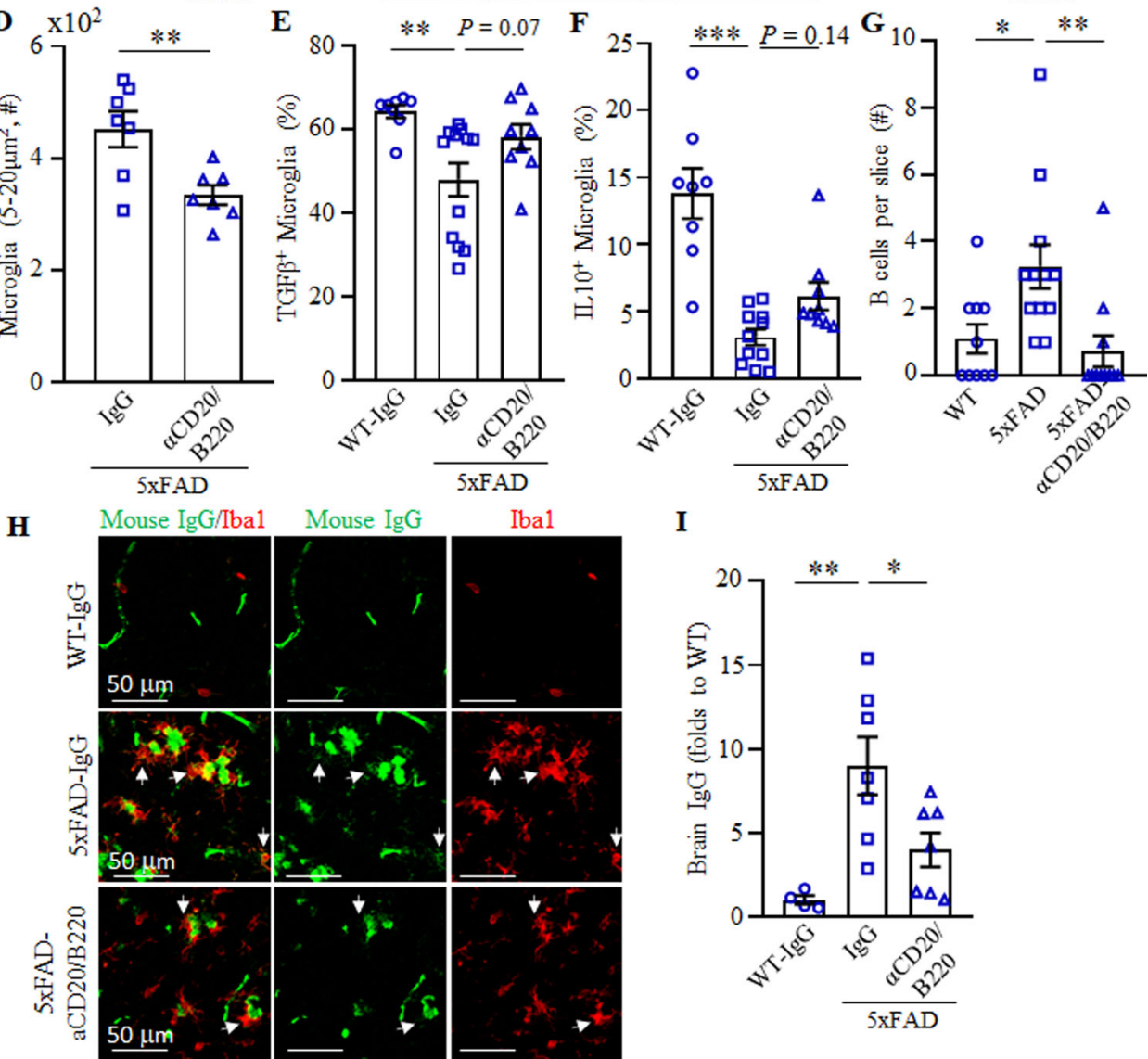

I

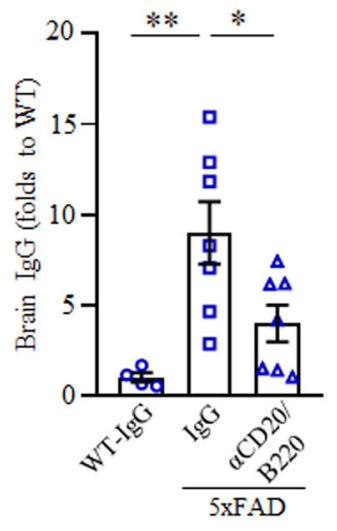

Fig. 5 Therapeutic depletion of B cells improves AD symptoms in $\mathbf{5} \times \mathbf{F A D}$ mice. OFA test revealed that B-cell depletion improves the retarded locomotion of $5 \times F A D$ mice (A, total distance travelled in first $5 \mathrm{~min}$ ). B-cell depletion reduced $A \beta$ plaque burden in the hippocampus (B, C). Representative immune fluorescent staining images for $A \beta$ plaques (green), Iba1+ microglia (red), and DAPI (cyan) are shown in $\mathbf{B}$. In $\mathbf{C}$ and $\mathbf{D}$, the results of quantification of $A \beta$ plaques and microglia are shown (D, large size, 5-20 $\mu \mathrm{m}^{2}$ ), respectively. A-D Results were reproduced twice, $n=7-12$. Flow cytometric evaluation of brain microglia $\left(C D 11 b^{+} C D 45^{\text {int }}\right)$ revealed that B-cell depletion increases the frequency (\%) of TGF $\beta+(\mathbf{E})$ and IL10 $+(\mathbf{F})$ microglia in $5 \times F A D$ mice $(n=10-12)$. As shown with immune fluorescent staining, B220+ B cells were markedly increased in the brain parenchyma of $5 \times F A D$ compared with WT controls, which was lost after transient B-cell depletion $(\mathbf{G}, n=9-12)$. The brains of $5 \times F A D$ mice contained high levels of $\lg$ as compared with WT controls, which was also reversed by transient depletion of $\mathrm{B}$ cells $(\mathbf{H}$ and $\mathbf{I})$. In $\mathbf{H}$, IgG is green and Iba1+ microglia is red. Brain IgG quantification is in $\mathbf{I}(n=5-7)$. Mean $\pm \mathrm{SEM}$ is shown; each symbol is for a single mouse. Gating strategy is shown in Supplementary Fig. 9B. ${ }^{\star} p<0.05 ;{ }^{\star \star} p<0.01 ;{ }^{* \star} p<0.001$ in one-way ANOVA $(\mathbf{A}, \mathbf{E}, \mathbf{F}, \mathbf{I})$, Kruskal-Wallis test $(\mathbf{G})$, or unpaired $t$ test $(\mathbf{C}, \mathbf{D})$.

decreased in $5 \times \mathrm{FAD}$ mouse brains as compared with that of WT mice $(p<0.001$, Fig. 5E, F). B-cell depletion reversed the decrease of TGF $\beta^{+}$and IL10 $0^{+}$microglia in $5 \times \mathrm{FAD}$ mice (Fig. 5E, F). As in other models, the treatment did not decrease hippocampal IL1 $\beta^{+}$ microglia (Supplementary Fig. 7A, B), presumably to support clearance of $A \beta$ plaques ${ }^{43}$. Collectively, we concluded that depletion of $\mathrm{B}$ cells can retard progression of $\mathrm{AD}$ even if applied at the onset of the disease.
We then wondered whether $\mathrm{B}$ cells promote $\mathrm{AD}$ by infiltrating the brain parenchyma. Since the low numbers of B cells $(<1 \%$ of $\mathrm{CD} 45^{+}$cells, not depicted) detected in flowcytometric analyses cannot discriminate between cells residing inside or outside of the parenchyma, we performed immune fluorescent staining of perfused and cryopreserved brain sections of mice. Unlike control age-matched WT mouse brains, we clearly detected a significant increase of $\mathrm{B}$ cells in the parenchyma of frontal cortex and 
hippocampus of 5xFAD mice (Fig. 5G and Supplementary Fig. 7C-E). Importantly, this increase of $\mathrm{B}$ cells was almost completely lost in B-cell-depleted 5×FAD mice (Fig. 5G and Supplementary Fig. 7D, E), implying that the cells originated in the circulation. We also stained the brain sections for the presence of IgG. While WT mouse brains were almost devoid of immunoglobulin (Fig. 5H, I), readily detectable and numerous IgG foci were present in the hippocampus parenchyma of $5 \times \mathrm{FAD}$ mice often colocalized with microglia and $\mathrm{A} \beta$ plaques (Fig. $5 \mathrm{H}, \mathrm{I}$ ). This brain IgG increase was lost in B-cell-depleted $5 \times \mathrm{FAD}$ mice (Fig. 5H, I). However, the depletion did not affect levels of total IgG nor minuscule amounts of $A \beta$-specific antibody in the circulation (Supplementary Fig. 8A-C), implying that $\mathrm{B}$ cells in the brain parenchyma produced IgG and presumably promoted $\mathrm{AD}$.

\section{Discussions}

Taken together, we provide counterintuitive evidence for a "dark" side of B cells-they exacerbate manifestation of AD-like symptoms in addition to producing potentially beneficial $A \beta$ plaquereducing immunoglobulins $s^{17-21}$ and expressing $\mathrm{AD}$-ameliorating cytokines $^{42}$. Although the exacerbation in Rag-deficient APP and $5 \times \mathrm{FAD}$ mice is linked to the loss of protective $\mathrm{B}$ cells and $\mathrm{T}$ cells ${ }^{16,21}$, our data revealed that the genetic loss of $\mathrm{B}$ cells alone or their transient depletion at the onset of $\mathrm{AD}$ improves the disease symptoms of three different mouse models. Unlike a recent report that linked $\mathrm{AD}$ progression to the reduction of antiinflammatory B1a cells in $5 \times \mathrm{FAD}$ mice ${ }^{42}$, the numbers of B1a and $\mathrm{B} 1 \mathrm{~b}$ cells in $\mathrm{PB}$, spleen, and cLN were either unaffected (in $5 \times \mathrm{FAD}$ mice even when followed for 4,7 , and 12 months) or upregulated (in $3 \times \mathrm{TgAD}$ and $\mathrm{APP} / \mathrm{PS} 1$ mice). However, regardless of their numbers, we recently reported that the function of B1a cells is not static and is rather controlled by the inflammatory milieu. In the aged hosts, B1a cells lose their anti-inflammatory activity and acquire pathogenic functions, such as becoming 4$1 \mathrm{BBL}^{+} \mathrm{B1a}$ cells (termed $4 \mathrm{BL}$ cells) that induce cytolytic granzyme- $\mathrm{B}^{+} \mathrm{CD}^{+} \mathrm{T}$ cells and promote insulin resistance ${ }^{23,44}$. In concordance, B1 cells (as well B2 cells, in some models) in AD mice also appeared to acquire an inflamed phenotype, as they upregulated expression of cytokines, such as IFN $\gamma$, IL6, TNFa, and IL10, and/or upregulated TGF $\beta$ and 4-1BBL. Although ageassociated $\mathrm{B}$ cells $\left(\mathrm{CD} 21^{-} \mathrm{CD} 23^{-} \mathrm{CD} 19^{+}\right)$also accumulate in aging, we did not detect their involvement in our three types of mice with $\mathrm{AD}$.

Consistent with a recent RNA-seq report that revealed presence of mature $\mathrm{B}$ cells in the brains of $\mathrm{AD}$ mice $^{4}$, our data indicate that $\mathrm{AD}$ increases $\mathrm{B}$ cells in the brain, and their $\operatorname{IgG}$ in the cortex and hippocampus parenchyma, which was often colocalized with $A \beta$ plaques and activated microglia. As in multiple sclerosis and cognitive dysfunction following stroke ${ }^{45-47}$, B cells in the brain presumably produce immunoglobulins and proinflammatory factors exacerbating $\mathrm{AD}$-promoting neuroinflammation. First, transfer of IgG from the circulation into the brain is an inefficient process, as only $0.0017 \%$ of intravenously injected immunoglobulin reaches the hippocampus of WT and $\mathrm{AD}$ mice ${ }^{48}$. Second, consistent with presumed ability of the intra-blood-brain-barrier sites of $\mathrm{AD}$ patients to synthesize immunoglobulin ${ }^{49}$, transient depletion of $\mathrm{B}$ cells in $5 \times \mathrm{FAD}$ mice significantly decreased brain B cells and IgG without affecting $\mathrm{A} \beta$-specific and nonspecific antibody levels in sera. Although immunoglobulin is thought to activate and promote microglial uptake of $A \beta$ plaques $^{21}$, the $A \beta-\operatorname{IgG}$ complex in CSF is thought to negatively affect the cognitive status of $\mathrm{AD}$ patients ${ }^{50}$. Our data also indicate that the loss of $B$ cells, thus IgG, in the brain significantly retards the development of AD. Although the mechanism of this process is a topic of a different study, we think that brain IgG (or its immune complex) alone or in concert with B-cell cytokines exacerbates neuroinflammation in AD. To do this, the brain IgG presumably targets chronically stressed DAMs (and other brain cells) ${ }^{4}$ through their upregulated Fc-receptors and complement ${ }^{51-53}$, as recently shown for myelin-IgG immune complexes from the brain of people with multiple sclerosis, which break immune tolerance of human microglia to microbial stimuli and cause harmful neuroinflammation via $\mathrm{Fc} \gamma \mathrm{RI}$ and $\mathrm{Fc} \gamma \mathrm{RIIa}{ }^{54}$. This in turn leads to downregulation of $\mathrm{TGF}^{+}$microglia, i.e., reduction in survival of resting M0 microglia and $A \beta$ plaque clearance $3,40,55$. Similar decrease in expression of TGF $\beta$ in DAM and increase in signals of mature $B$ cells is also noted in recent brain RNA-seq results of $\mathrm{AD}$ mice ${ }^{4}$. Conversely, the loss of $\mathrm{B}$ cells increased TGF $\beta^{+}$microglia as well downregulated expression of Trem2, Clec7a, and Itgax in the hippocampus, i.e., replacement of DAM with microglia that eliminate $A \beta$ oligomers and other neurotoxic debris ${ }^{8-10}$, reduced $A \beta$ plaques and improved behavioral impairments of our $\mathrm{AD}$ mice. It is tempting to speculate that $\mathrm{B}$ cells similarly participate in EOAD in humans, as the severity of the disease in humans with mild $\mathrm{AD}$ is correlated with accumulation of double negative memory CCR6 ${ }^{+} \mathrm{B}$ cells in the circulation ${ }^{56}$. Moreover, elderly humans accumulate pathogenic $4-1 \mathrm{BBL}^{+} \mathrm{TNFa}^{+} \mathrm{B}$ cells that induce antigen-specific $\mathrm{CD} 8^{+} \mathrm{T}$ cells and promote insulin resistance ${ }^{22,23}$, two events linked to $\mathrm{AD}^{57,58}$. We therefore propose that the inactivation of $\mathrm{B}$ cells can also benefit humans with $\mathrm{AD}$, as therapeutic $\mathrm{B}$-cell removal even at the onset of the disease reversed manifestation of $\mathrm{AD}$ in mice.

\section{Methods}

Mice. The animal protocols were approved and permission was granted to perform animal experiments by the ACUC committee of the National Institute on Aging (ASP 321-LMBI-2022) under the Guide for the Care and Use of Laboratory Animals (NIH Publication No. 86-23, 1985). AD transgenic mice (5-80 weeks of age, females) were bred, aged, and housed in the same, specific pathogen-free environment at the National Institute on Aging (NIA). Female C57BL/6j mice (Stock \# 000664) were purchased from Jackson Laboratory (Bar Harbor, ME) and congenic $3 \times \mathrm{TgAD}$ mice (triple transgenic with three human genes associated with familial AD, B6;129-Psen $1^{\text {tm1Mpm }}$ Tg(APPSwe,tauP301L)1 Lfa/Mmjax) $)^{24,25}$, APP/PS1 mice (B6.Cg- $\mathrm{Tg}$ (APPswe,PSEN1DE9) $85 \mathrm{Dbo} / \mathrm{J})^{16}, 5 \times \mathrm{FAD}$ mice expressing mutant human APP and PSEN1 genes (B6.Cg-Tg;APPSwFILon,PSEN1*M146L*L286V) ${ }^{21}$ and $\mathrm{J}_{\mathrm{H}} \mathrm{T}$ mice (B6.129P2-Igh-J $\left.J^{t m 1 C g n} / \mathrm{J}\right)$, which do not develop functional B cells in the circulation due to the immunoglobulin $\mathrm{J}_{\mathrm{H}}$ locus deletion ${ }^{26}$, were bred and maintained at NIA, Baltimore, MD. Transient B-cell depletion was performed as previously reported ${ }^{22,59}$, such as mice were injected intraperitoneally (i.p., three to six times for 2-3 months) with anti-CD20 Ab (clone 5D2, Genetech, $100 \mu \mathrm{g} /$ mouse) and anti-B220 Ab (150 $\mu \mathrm{g} /$ mouse, TIB-146, BioXCell $)$.

Tissues and blood processing. Single-cell suspension of spleen and cLN was prepared using a $70 \mu \mathrm{m}$ cell strainer (BD Falcon, Bedford, MA). Blood was col lected in tube with $2 \mathrm{mg} / \mathrm{ml}$ of Na-heparin (Sigma). Spleen and blood cell suspensions were treated with ACK buffer to remove red blood cells. The brains were dissociated with Adult Brain Dissociation kit for mouse and rat (MiltenyiBiotec, Auburn, CA) using GentleMACS ${ }^{\text {m }}$ Dissociator (MiltenyiBiotec), following the manufacturer's instruction.

Flow cytometry (FACS). Antibodies (Ab, see Supplementary Data 4) to mouse CD19, CD5, CD11b, CD43, 4-1BBL, IFN $\gamma$, IL1 $\beta$, TGF $\beta$, IL10, IL6, CD11b, and CD45 and their isotype-matched control $\mathrm{Ab}$ were purchased from Biolegend, eBioscience, BD Bioscience, and R\&D Systems, unless specified. For IC cytokine staining, cells were stimulated with $50 \mathrm{ng} / \mathrm{ml}$ PMA (Tocris Bioscience) and $500 \mathrm{ng} / \mathrm{ml}$ ionomycin (Tocris Bioscience) for 1-2 h, followed by Golgi stop for 3-4 h using $10 \mu \mathrm{mol} / \mathrm{l}$ of Monensin or Brefeldin A (eBioscience); and then stained following manufacturer's instruction for IC fixation and permeabilization (eBioscience). Concentration of antibody used in FACS staining was $1 \mu \mathrm{g}$ per $10^{6}$ cells. Data were analyzed on FACS Canto II (BD) or CytoFLEX (Beckman Coulter, Inc.) using FlowJo software (Tree Star, Inc.) or CytExpert software (Beckman Coulter, Inc.).

Brain immune fluorescent staining. Mice were perfused with PBS for 20-30 min after euthanasia with $\mathrm{CO}_{2}$, and the brains were removed and washed with PBS, and then half brain was fixed by $4 \%$ PFA in PBS. After 24 -h fixation, the brain was transferred to PBS buffer containing 30\% sucrose in $15 \mathrm{ml}$ tubes for $\sim 2$ days until the brain sank to the bottom. Next, the brains were embedded in OCT compound, frozen on dry ice and stored in $-80^{\circ} \mathrm{C}$ before cryosection. A total of $30-\mu \mathrm{m}$ thick coronal 
sections containing hippocampus were collected with $240 \mu \mathrm{m}$ interval to get eight sets and two to six slices of each mouse were stained for each immunofluorescence staining. For immunofluorescence staining, we adopted free-floating staining method: after two washes with PBS, the brain slices were incubated in $0.3 \mathrm{M}$ glycine buffer for $30 \mathrm{~min}$ at room temperature (RT), and then blocked and permeabilized with IF buffer ( $2 \%$ donkey serum, $2 \% \mathrm{BSA}$, and $0.1 \%$ Triton X-100 in PBS) for 30-60 min at RT. Brain slices were incubated with designated Abs or their isotype control immunoglobulins purchased from Abcam, overnight at $4{ }^{\circ} \mathrm{C}$ followed by 15-60-min incubations at RT. After three washes with PBS, brain slices were incubated with fluorochrome-conjugated secondary Abs from Abcam (Donkey anti-mouse IgG H\&LAlexa Fluor 488; Donkey anti-rabbit IgG H\&L-Alexa Fluor 568; Donkey anti-rat IgG H\&L-Alexa Fluor 568; Donkey anti-goat IgG H\&L-Alexa Fluor 647;) at RT for $2 \mathrm{~h}$. After three washes with PBS, slides were mounted with ProLong ${ }^{\text {me }}$ Gold/Diamond Antifade Mountant with DAPI (Invitrogen). For IgG staining, brain slices were incubated with Ibal antibody for $2 \mathrm{~h}$ at RT followed by wash with PBS, and then incubated with Alexa Fluor 488 labeled F( $\left.\mathrm{ab}^{\prime}\right) 2$-Goat anti-Mouse IgG $(\mathrm{H}+\mathrm{L})$ Antibody (cat \# A-11017) and Donkey anti-rabbit IgG H\&L-Alexa Fluor 568. The information of the first antibodies used is as below: purified anti- $\beta$-Amyloid, 1-16 Antibody (clone 6E10, cat \# 803002), Recombinant Anti-Ibal antibody (cat \# ab178846), Mouse IL1 beta /IL-1F2 Antibody (cat \# AF-401-NA), Anti-CD45R (B220) antibody (cat \# ab64100), ZO-1 Polyclonal Antibody (cat \# 40-2300), and Mouse Laminin alpha 4 Antibody (cat \# AF3837).

Images were acquired with a Zeiss LSM 710 confocal microscope equipped with a $\times 20 / 0.8$ and a $\times 20$ Plan-Apochromat dry objectives (Carl Zeiss). For $A \beta$ plaque and microglia quantification, subculum region for $3 \times \mathrm{TgAD}$ model, or dentate gyrus region for APP/PS1 model, or whole hippocampus region for $5 \times \mathrm{FAD}$ model were respectively identified in the coronal brain slices and imaged. For brain IL1 $\beta$ or IgG quantification, subculum region was imaged. For brain B220 ${ }^{+}$B-cell quantification, the whole brain was observed and images for $\mathrm{B} 220^{+} \mathrm{B}$ cells were captured. The quantification of all images was performed with ImageJ software. For $A \beta$ and microglia quantification, the image of up to six slices per mouse were acquired and quantified in the subiculum region $(3 \times \mathrm{TgAD}$ model), DG region (APP/PS1 model), or whole hippocampus (5XFAD model). Briefly, the single channel image was converted into 8-bit image and proper threshold was chosen and fixed for all the images in the same experiment, then "analyze particles" function was used for quantified the number or area of $6 \mathrm{E} 10$ plaque and $\mathrm{Iba}^{+}$ microglia. The representative image for microglia quantification was shown in Supplementary Fig. 3G. For B220+ B-cell quantification, the whole brain region was carefully observed and the images of $\mathrm{B} 220^{+} \mathrm{B}$ cells were acquired, and the location of $\mathrm{B}$ cells was distinguished by ZO-1 or laminin a4 staining or bright field.

Measurement of soluble $\mathbf{A} \boldsymbol{\beta}_{\mathbf{4 0} / \mathbf{4 2}}$ peptides. Cerebral cortex and hippocampus were separated from PBS-perfused mouse brains, and stored at $-80^{\circ} \mathrm{C}$. Soluble and insoluble protein fractions were purified using a modification of previously published protocol for $A \beta$ peptides $^{60}$. Briefly, tissues were mechanically homogenized in in TBSTriton $1 \%(120 \mathrm{mM} \mathrm{NaCl}, 50 \mathrm{mM}$ Tris, $\mathrm{pH}$ 8.0, $150 \mathrm{mg} / \mathrm{ml}$ (tissue/buffer)), including protease inhibitor cocktail (1:100, P2714, Sigma, St. Louis, MO), then incubated on ice for $30 \mathrm{~min}$ followed by centrifugation for $120 \mathrm{~min}$ at $17,000 \times g$ at $4{ }^{\circ} \mathrm{C}$. Supernatant, containing TBS-T-soluble fraction of mouse $A \beta 1-40$ and $A \beta 1-42$ was removed and stored at $-20^{\circ} \mathrm{C}$. The remaining pellet, containing insoluble $A \beta$ was resuspended in $70 \%$ formic acid and incubated on ice for $30 \mathrm{~min}$, followed by centrifugation at the same conditions as mentioned above. Formic acid-soluble supernatant was separated and neutralized using $1 \mathrm{M}$ Tris ( $\mathrm{pH}=11,20$-time the volume of the formic acid) and stored at $-20^{\circ} \mathrm{C}$. Total protein concentration was determined using the BCA method (cat \# 23225, Thermo Fisher Scientific, Waltham, MA). TBS-S and formic acid soluble levels $A \beta_{1-40}$ and $A \beta_{1-42}$ in the cortex were measured using sandwich-ELISA protocol in 96-well polystyrene microplates (655061, Greinerbio-one, Monroe, NC) were covered with $50 \mu \mathrm{l}$ of anti-rabbit-N-terminus $\mathrm{A} \beta_{1-14}$ (ab2539, Abcam, Cambridge, UK) at a concentration of $5 \mu \mathrm{g} / \mathrm{ml}$ in carbonate-bicarbonate buffer $(\mathrm{pH}=9.6)$ and incubated overnight at $4{ }^{\circ} \mathrm{C}$. Plates were washed four times in PBS-T solution $(0.1 \%$ Triton $\mathrm{X}$ in PBS) and blocked with $2 \%$ BSA solution in PBS. A total of $50 \mu$ l of tissue homogenate were applied to each well, and incubated for $60 \mathrm{~min}$ at RT. Plates were then washed five times in PBS-T, and the following detection antibodies were added: Anti- $\mathrm{A} \beta_{1-40}$ antibody (ab20068, Abcam, Cambridge, UK) diluted at 1:500 or anti $\mathrm{A} \beta_{1-42}$ antibody (05-831, Millipore, Billerica, MA) at 1:2500, and incubated for $60 \mathrm{~min}$ at RT. Next, plates were washed five times in PBS-T and secondary goat anti-mouse IgG HRPconjugated antibody was added (115-035-003, Peroxidase AffiniPure Goat Anti-

Mouse, Jackson immunoresearch, PA) at a dilution of 1:5000. Plates were washed five times with PBS-T and $50 \mu \mathrm{l}$ of 3, 3', 5, 5'-tetramethylbenzidine substrate (00-4201-56, Affimetrix eBioscience, San Diego, CA) was added. The color reaction was allowed to develop for $3 \mathrm{~min}$ and was stopped by adding $50 \mu \mathrm{l}$ of $2 \mathrm{M} \mathrm{H}_{2} \mathrm{SO}_{4}$. Optical density was measured at $450 \mathrm{~nm}$ using a spectrophotometer. Standard curve was carried out using known concentrations of recombinant $A \beta_{1-40}$ and $A \beta_{1-42}$.

Behavioral tests. For the MWM test, we used a $140-\mathrm{cm}$-diameter tub containing a $15 \times 15 \mathrm{~cm}$ square platform submerged $1 \mathrm{~cm}$ below the water surface. Water was maintained at $21 \pm 1{ }^{\circ} \mathrm{C}$ and colored with white paint. Mice underwent four trials per day, released from each of four compass points $(\mathrm{N}, \mathrm{S}, \mathrm{W}, \mathrm{E})$ in a randomized order. If a mouse did not find the hidden platform within $60 \mathrm{~s}$, it was gently guided to the platform. All mice remained on the platform for $10 \mathrm{~s}$ at the end of each trial, were towel tried, and returned to their home cage. After 5 days of training mice were subjected to a 60 -s probe trial that took place $24 \mathrm{~h}$ after the last training trial. The platform was removed and mice were placed on the opposite wall at the point furthest from the former platform location. The day after the probe trial, mice were tested for four trials in their ability to swim to a visible platform. Swimming was analyzed with ANY-Maze software (Stoelting). For the open field test, mice were placed in a $34 \times 34 \times 25 \mathrm{~cm}$ white acrylic chamber and recorded by overhead camera for $60 \mathrm{~min}$. Because the first few minutes in this test are maximally sensitive to $\mathrm{AD}$ transgenic mice ${ }^{30}$, we focused analysis on the initial 5 minutes. Tracks were analyzed with ANY-Maze software. Analysis in all behavior experiments was performed using ANY-Maze software. For the gait analysis, mice were tested on a fixed-speed treadmill apparatus (DigiGait; Mouse Specifics). Mice were habituated to the apparatus for $1 \mathrm{~min}$, and then given a 1 - $\mathrm{min}$ run at $5 \mathrm{~cm} / \mathrm{s}$. Following a 1 min rest, the treadmill speed was increased to $15 \mathrm{~cm} / \mathrm{s}$. Video was collected at high speed from a ventrally placed camera, and 3-5 s of representative gait video was selected by an experienced user for automated analysis.

Microarray analysis. From PBS-perfused brains or hippocampi of mice, total RNA was isolated with RNeasy Plus micro kit (QIAGEN) according to manufacturer's instruction. Microarray analysis was performed using the Illumina and Agilent platforms, then we quantile-normalized the gene expression profiles ${ }^{61}$, $\log 2$-transformed the raw probe intensity values and estimated the gene expression using the probe with the highest average expression ${ }^{62}$. Microarray data are submitted at https://www.ncbi.nlm.nih.gov/geo/query/acc.cgi?acc=GSE165111.

Immunoglobulin ELISA. Blood was collected in BD Microtainer ${ }^{\circledR}$ Tubes and serum was separated by centrifugation following the manufacturer's instruction. For $A \beta$ specific immunoglobulin ELISA, sera (diluted in $0.05 \%$ Tween $20 / 2 \%$ BSA/PBS) were incubated in 96-well plates coated with $4-8 \mu \mathrm{g} / \mathrm{ml} \mathrm{A} \beta_{1-42}$ peptide (AnaSpec, cat \# AS-24224) and quantified using HRP-conjugated goat anti-mouse IgA, IgM, or IgG antibodies. For serum immunoglobulin ELISA, Ig Isotyping Mouse Uncoated ELISA Kit (Invitrogen, Cat No. \# 88-50630-88) was used, following the manufacturer's instruction.

Statistical analysis. All statistical analyses were performed with GraphPad Prism (Prism 8; Graph Pad Software, Inc.). Normality tests were conducted to decide whether the data are from normally distributed population. Unpaired $t$ test or oneway ANOVA, for two groups or three groups, respectively, was used if the data are considered to be normally distributed, otherwise Mann-Whitney test or Kruskal-Wallis test was used for two groups or three groups, respectively. Due to changes in variance across days of invisible platform testing in MWM, as is typical in this task ${ }^{63}$, each day was individually analyzed using one-way ANOVA. Bonferroni post hoc tests were conducted when appropriate. The results were presented as the mean with each individual data point or in bar graph \pm SEM. A $p$ value $<0.05$ was considered significant $\left({ }^{*} p<0.05,{ }^{* *} p<0.01\right.$, and $\left.{ }^{* * *} p<0.001\right)$

Reporting summary. Further information on research design is available in the Nature Research Reporting Summary linked to this article.

\section{Data availability}

All data associated with this study can be found in the paper or supplementary materials. The microarray data are deposited at https://www.ncbi.nlm.nih.gov/geo/query/acc.cgi? acc $=$ GSE165111. Source data are provided with this paper

Received: 10 December 2019; Accepted: 12 March 2021; Published online: 12 April 2021

\section{References}

1. Hardy, J. \& Selkoe, D. J. The amyloid hypothesis of Alzheimer's disease: progress and problems on the road to therapeutics. Science 297, 353-356 (2002).

2. Ma, D. et al. TGF-beta induced by interleukin-34-stimulated microglia regulates microglial proliferation and attenuates oligomeric amyloid beta neurotoxicity. Neurosci. Lett. 529, 86-91 (2012).

3. Tichauer, J. E. \& von Bernhardi, R. Transforming growth factor-beta stimulates beta amyloid uptake by microglia through Smad3-dependent mechanisms. J. Neurosci. Res. 90, 1970-1980 (2012).

4. Keren-Shaul, H. et al. A unique microglia type associated with restricting development of alzheimer's disease. Cell 169, 1276-1290 e1217 (2017).

5. Brionne, T. C., Tesseur, I., Masliah, E. \& Wyss-Coray, T. Loss of TGF-beta 1 leads to increased neuronal cell death and microgliosis in mouse brain. Neuron 40, 1133-1145 (2003).

6. Monje, M. L., Toda, H. \& Palmer, T. D. Inflammatory blockade restores adult hippocampal neurogenesis. Science 302, 1760-1765 (2003). 
7. Ekdahl, C. T., Claasen, J. H., Bonde, S., Kokaia, Z. \& Lindvall, O. Inflammation is detrimental for neurogenesis in adult brain. Proc. Natl Acad. Sci. USA 100, 13632-13637 (2003).

8. Rogers, J., Strohmeyer, R., Kovelowski, C. J. \& Li, R. Microglia and inflammatory mechanisms in the clearance of amyloid beta peptide. Glia 40, 260-269 (2002).

9. DeWitt, D. A., Perry, G., Cohen, M., Doller, C. \& Silver, J. Astrocytes regulate microglial phagocytosis of senile plaque cores of Alzheimer's disease. Exp. Neurol. 149, 329-340 (1998).

10. Mawuenyega, K. G. et al. Decreased clearance of cns beta-amyloid in Alzheimer's disease. Science 330, 1774-1774 (2010).

11. in t' Veld, B. A. et al. Nonsteroidal antiinflammatory drugs and the risk of Alzheimer's disease. N. Engl. J. Med. 345, 1515-1521 (2001).

12. Thevaranjan, N. et al. Age-associated microbial dysbiosis promotes intestinal permeability, systemic inflammation, and macrophage dysfunction. Cell Host Microbe 21, 455-466 e454 (2017).

13. Holmes, C. et al. Systemic infection, interleukin 1beta, and cognitive decline in Alzheimer's disease. J. Neurol. Neurosurg. Psychiatry 74, 788-789 (2003).

14. Fisher, Y., Nemirovsky, A., Baron, R. \& Monsonego, A. T cells specifically targeted to amyloid plaques enhance plaque clearance in a mouse model of Alzheimer's disease. PLoS ONE 5, e10830 (2010).

15. Browne, T. C. et al. IFN-gamma production by amyloid beta-specific Th1 cells promotes microglial activation and increases plaque burden in a mouse model of Alzheimer's disease. J. Immunol. 190, 2241-2251 (2013).

16. Spani, C. et al. Reduced beta-amyloid pathology in an APP transgenic mouse model of Alzheimer's disease lacking functional B and T cells. Acta Neuropathol. Commun. 3, 71 (2015).

17. Gold, M., Mengel, D., Roskam, S., Dodel, R. \& Bach, J. P. Mechanisms of action of naturally occurring antibodies against beta-amyloid on microglia. $J$. Neuroinflammation 10, 5 (2013).

18. Britschgi, M. et al. Neuroprotective natural antibodies to assemblies of amyloidogenic peptides decrease with normal aging and advancing Alzheimer's disease. Proc. Natl Acad. Sci. USA 106, 12145-12150 (2009).

19. Morgan, D. et al. A beta peptide vaccination prevents memory loss in an animal model of Alzheimer's disease. Nature 408, 982-985 (2000).

20. Olkhanud, P. B. et al. DNA immunization with HBsAg-based particles expressing a B cell epitope of amyloid beta-peptide attenuates disease progression and prolongs survival in a mouse model of Alzheimer's disease. Vaccine 30, 1650-1658 (2012).

21. Marsh, S. E. et al. The adaptive immune system restrains Alzheimer's disease pathogenesis by modulating microglial function. Proc. Natl Acad. Sci. USA 113, E1316-E1325 (2016).

22. Lee-Chang, C. et al. Accumulation of $4-1 B B L+B$ cells in the elderly induces the generation of granzyme- $\mathrm{B}+\mathrm{CD} 8+\mathrm{T}$ cells with potential antitumor activity. Blood 191, 4141-4151 (2014).

23. Bodogai, $M$. et al. Commensal bacteria contribute to insulin resistance in aging by activating innate B1a cells. Sci. Transl. Med. 10, eaat4271 (2018).

24. Oddo, S. et al. Triple-transgenic model of Alzheimer's disease with plaques and tangles: intracellular Abeta and synaptic dysfunction. Neuron 39, 409-421 (2003).

25. Sterniczuk, R., Antle, M. C., Laferla, F. M. \& Dyck, R. H. Characterization of the $3 \times \mathrm{Tg}-\mathrm{AD}$ mouse model of Alzheimer's disease: part 2. Behavioral and cognitive changes. Brain Res. 1348, 149-155 (2010).

26. Chen, J. et al. Immunoglobulin gene rearrangement in B cell deficient mice generated by targeted deletion of the JH locus. Int. Immunol. 5, 647-656 (1993).

27. Filali, M. et al. Cognitive and non-cognitive behaviors in the triple transgenic mouse model of Alzheimer's disease expressing mutated APP, PS1, and Mapt (3xTg-AD). Behav. Brain Res. 234, 334-342 (2012).

28. Chiquita, S. et al. A longitudinal multimodal in vivo molecular imaging study of the $3 \times \mathrm{Tg}-\mathrm{AD}$ mouse model shows progressive early hippocampal and taurine loss. Hum. Mol. Genet. 28, 2174-2188 (2019).

29. Borchelt, D. R. et al. Accelerated amyloid deposition in the brains of transgenic mice coexpressing mutant presenilin 1 and amyloid precursor proteins. Neuron 19, 939-945 (1997).

30. O'Leary, T. P., Hussin, A. T., Gunn, R. K. \& Brown, R. E. Locomotor activity, emotionality, sensori-motor gating, learning and memory in the APPswe/ PS1dE9 mouse model of Alzheimer's disease. Brain Res. Bull. 140, 347-354 (2018).

31. Atwood, C. S. \& Bowen, R. L. A unified hypothesis of early- and late-onset Alzheimer's disease pathogenesis. J. Alzheimers Dis. 47, 33-47 (2015).

32. Roda, A. R., Esquerda-Canals, G., Marti-Clua, J. \& Villegas, S. Cognitive impairment in the 3xTg-AD mouse model of alzheimer's disease is affected by abeta-immunotherapy and cognitive stimulation. Pharmaceutics 12, 944 (2020).

33. Greene, S. J. \& Killiany, R. J., Alzheimer's Disease Neuroimaging, I. Hippocampal subregions are differentially affected in the progression to Alzheimer's disease. Anat. Rec. 295, 132-140 (2012).
34. Stence, N., Waite, M. \& Dailey, M. E. Dynamics of microglial activation a confocal time-lapse analysis in hippocampal slices. Glia 33, 256-266 (2001).

35. Bachstetter, A. D. et al. Disease-related microglia heterogeneity in the hippocampus of Alzheimer's disease, dementia with Lewy bodies, and hippocampal sclerosis of aging. Acta Neuropathol. Commun. 3, 32 (2015).

36. El Haji, H. et al. Ultrastructural evidence of microglial heterogeneity in Alzheimer's disease amyloid pathology. J. Neuroinflammation 16, 87 (2019).

37. Stebbing, M. J., Cottee, J. M. \& Rana, I. The role of ion channels in microglia activation and proliferation - a complex interplay between ligand-gated ion channels, $\mathrm{K}(+)$ channels, and intracellular $\mathrm{Ca}(2$.$) . Front. Immunol. 6, 497$ (2015).

38. Abutbul, S. et al. TGF-beta signaling through SMAD2/3 induces the quiescent microglial phenotype within the CNS environment. Glia 60, 1160-1171 (2012).

39. Schilling, T., Nitsch, R., Heinemann, U., Haas, D. \& Eder, C. Astrocytereleased cytokines induce ramification and outward $\mathrm{K}+$ channel expression in microglia via distinct signalling pathways. Eur. J. Neurosci. 14, 463-473 (2001).

40. Butovsky, O. et al. Identification of a unique TGF-beta-dependent molecular and functional signature in microglia. Nat. Neurosci. 17, 131-143 (2014).

41. Oakley, H. et al. Intraneuronal beta-amyloid aggregates, neurodegeneration, and neuron loss in transgenic mice with five familial Alzheimer's disease mutations: potential factors in amyloid plaque formation. J. Neurosci. 26, 10129-10140 (2006).

42. Baulch, J. E. et al. Immune and inflammatory determinants underlying Alzheimer's disease pathology. J Neuroimmune Pharmacol. 15, 852-862 (2020).

43. Shaftel, S. S. et al. Sustained hippocampal IL-1 beta overexpression mediates chronic neuroinflammation and ameliorates Alzheimer plaque pathology. J. Clin. Investig. 117, 1595-1604 (2007).

44. Lee-Chang, C. et al. Aging converts innate B1a cells into potent CD8+ T cell inducers. J. Immunol. 196, 3385-3397 (2016).

45. Michel, L. et al. B cells in the multiple sclerosis central nervous system: trafficking and contribution to CNS-compartmentalized inflammation. Front. Immunol. 6, 636 (2015).

46. Cepok, S. et al. Short-lived plasma blasts are the main B cell effector subset during the course of multiple sclerosis. Brain 128, 1667-1676 (2005).

47. Doyle, K. P. et al. B-lymphocyte-mediated delayed cognitive impairment following stroke. J. Neurosci. 35, 2133-2145 (2015).

48. St-Amour, I. et al. Brain bioavailability of human intravenous immunoglobulin and its transport through the murine blood-brain barrier. J. Cereb. Blood Flow. Metab. 33, 1983-1992 (2013).

49. Blennow, K. et al. Intra-blood-brain-barrier synthesis of immunoglobulins in patients with dementia of the Alzheimer type. Alzheimer Dis. Assoc. Disord. 4, 79-86 (1990).

50. Maftei, M. et al. Increased levels of antigen-bound beta-amyloid autoantibodies in serum and cerebrospinal fluid of Alzheimer's disease patients. PLoS ONE 8, e68996 (2013).

51. Chakrabarty, P. et al. IFN-gamma promotes complement expression and attenuates amyloid plaque deposition in amyloid beta precursor protein transgenic mice. J. Immunol. 184, 5333-5343 (2010).

52. Diamond, B., Huerta, P. T., Mina-Osorio, P., Kowal, C. \& Volpe, B. T. Losing your nerves? Maybe it's the antibodies. Nat. Rev. Immunol. 9, 449-456 (2009).

53. Doens, D. \& Fernandez, P. L. Microglia receptors and their implications in the response to amyloid beta for Alzheimer's disease pathogenesis. J. Neuroinflammation 11, 48 (2014).

54. van der Poel, M., Hoepel, W., Hamann, J., Huitinga, I. \& Dunnen, J. D. IgG immune complexes break immune tolerance of human microglia. J. Immunol. 205, 2511-2518 (2020).

55. Caraci, F. et al. TGF-beta 1 protects against Abeta-neurotoxicity via the phosphatidylinositol-3-kinase pathway. Neurobiol. Dis. 30, 234-242 (2008).

56. Bulati, M. et al. Double negative (IgG+IgD-CD27-) B cells are increased in a cohort of moderate-severe Alzheimer's disease patients and show a proinflammatory trafficking receptor phenotype. J. Alzheimers Dis. 44, 1241-1251 (2015).

57. Merlini, M., Kirabali, T., Kulic, L., Nitsch, R. M. \& Ferretti, M. T. Extravascular CD3 + T cells in brains of alzheimer disease patients correlate with tau but not with amyloid pathology: an immunohistochemical study. Neurodegener. Dis. 18, 49-56 (2018).

58. Ferreira, L. S. S., Fernandes, C. S., Vieira, M. N. N. \& De Felice, F. G. Insulin resistance in Alzheimer's Disease. Front. Neurosci. 12, 830 (2018).

59. Bodogai, M. et al. Anti-CD20 antibody promotes cancer escape via enrichment of tumor-evoked regulatory B cells expressing low levels of CD20 and CD137L. Cancer Res. 73, 2127-2138 (2013).

60. Illouz, T., Madar, R., Griffioen, K. \& Okun, E. A protocol for quantitative analysis of murine and human amyloid-beta1-40 and 1-42. J. Neurosci. Methods 291, 28-35 (2017). 
61. Dunning, M. J., Smith, M. L., Ritchie, M. E. \& Tavare, S. beadarray: R classes and methods for Illumina bead-based data. Bioinformatics 23, 2183-2184 (2007).

62. Miller, J. A. et al. Strategies for aggregating gene expression data: the collapseRows R function. BMC Bioinformatics 12, 322 (2011).

63. Vorhees, C. V. \& Williams, M. T. Morris water maze: procedures for assessing spatial and related forms of learning and memory. Nat. Protoc. 1, 848-858 (2006).

\section{Acknowledgements}

We are grateful to Dr. A. C. Chan (Genentech, Inc.) for providing anti-CD20 Ab; Drs. K. Becker, E. Lehrmann, and Y. Zhang (NIA) for microarray assay and bioinformatics analysis; and Mrs. A. Lustig (NIA) and Dr. Chandamany Arya (Lilly) for proofreading. This research was supported by the Intramural Research Program of the National Institute on Aging, NIH, and by grant NIH R01 AG054712-01A1.

\section{Author contributions}

K.K., X.W., E.Ra., and M.B. performed the research and collected and analyzed data; T.I. M.D., and R.M. performed experiments; F.G. provided bioinformatics support, E.Ro. and E.O. provided critical interpretation; and A.B. wrote the manuscript and conceived, designed, and supervised the study.

\section{Funding}

Open Access funding provided by the National Institutes of Health (NIH).

\section{Competing interests}

The authors declare no competing interests.

\section{Additional information}

Supplementary information The online version contains supplementary material available at https://doi.org/10.1038/s41467-021-22479-4.

Correspondence and requests for materials should be addressed to A.B.

Peer review information Nature Communications thanks Jacques Galipeau and the other, anonymous, reviewer(s) for their contribution to the peer review of this work. Peer reviewer reports are available.

Reprints and permission information is available at http://www.nature.com/reprints

Publisher's note Springer Nature remains neutral with regard to jurisdictional claims in published maps and institutional affiliations.

\begin{abstract}
(c) (i)
Open Access This article is licensed under a Creative Commons Attribution 4.0 International License, which permits use, sharing, adaptation, distribution and reproduction in any medium or format, as long as you give appropriate credit to the original author(s) and the source, provide a link to the Creative Commons license, and indicate if changes were made. The images or other third party material in this article are included in the article's Creative Commons license, unless indicated otherwise in a credit line to the material. If material is not included in the article's Creative Commons license and your intended use is not permitted by statutory regulation or exceeds the permitted use, you will need to obtain permission directly from the copyright holder. To view a copy of this license, visit http://creativecommons.org/ licenses/by/4.0/.
\end{abstract}

This is a U.S. government work and not under copyright protection in the US; foreign copyright protection may apply 2021 